\title{
PEMANFAATAN TEKNOLOGI AUGMENTED REALITY PADA MEDIA PENGENALAN BANGUNAN BERSEJARAH RUMAH KEDIAMAN BUNG KARNO BENGKULU BERBASIS ANDROID
}

\author{
Dedy Abdullah ${ }^{1}$, Alkausar Sani ${ }^{2}$, Amir Hasan $^{3}$ \\ 1,2,3 Program Studi Informatika, Fakultas Teknik, Universitas Muhammadiyah Bengkulu \\ Jl. Bali PO BOX 118 Telp (0736)227665’ FAX (0736)26161, Bengkulu 38119

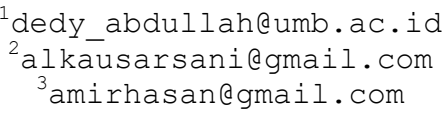

Abstrak: Pemanfaatan teknologi mulai berkembang dari masa ke masa, bayangkan saja dari yang dulu hanya bisa mendengarkan suara lewat radio, kemudian berkembang dengan hadirnya televisi walau hanya 2 warna, sekarang telah berubah menjadi masa kejayaan teknologi portable seperti smartphone. Rumah kediaman Bung Karno merupakan salah satu bangunan bersejarah peninggalan Ir. Soekarno semasa pengasingan yang terletak di kota Bengkulu. Letaknya yang berada di pusat kota Bengkulu menjadikannya salah satu obyek wisata utama kota Bengkulu. Kurangnya informasi dan media promosi yang kurang menarik dan tidak interaktif menyebabkan pengunjung yang datang ke lokasi ini masih sangat sedikit. Penelitian ini mengugunakan metode incremental. Hasil penelitian menunjukkan sistem aplikasi augmented reality Rumah Kediaman Bung Karno berjalan dengan baik. Jarak yang baik dalam proses tracking pada marker adalah $27 \mathrm{~cm}$, sudut pandang yang baik adalah $0^{0}-45^{0}$ serta cahaya yang baik adalah $100 \mathrm{~lm} / \mathrm{m}^{2}-400 \mathrm{~lm} / \mathrm{m}^{2}$.

Kata kunci : Augmented Reality, Rumah Kediaman Bung Karno, incremental, Obyek wisata, Bengkulu.

\begin{abstract}
Utilization technology developed rapidly in the community from which only able to listen the sound through radio, then developed with the presence of television that has been able to display audio visual, has now been transformed into a technology Portable such as Smartphones. The residence of Bung Karno is one of the historical buildings left by Ir. Soekarno during his exile located in the city of Bengkulu. Its location in the center of the city of Bengkulu makes it one of the main tourist attractions in the city of Bengkulu. lack of information and promotional media causes very few visitors to this location. This research using the incremental method. The results showed the system application augmented reality Home residence of Bung Karno Stadium has gone well. A good distance in the process of tracking marker is $27 \mathrm{~cm}$, a good vantage point is $0^{\circ}-45^{\circ}$ as well as good light is $100 \mathrm{~lm} / \mathrm{m}^{2}-400 \mathrm{~lm} / \mathrm{m}^{2}$.
\end{abstract}

Keywords: Augmented Reality, The Home Residence Of Bung Karno, Tourism object.

\section{PENDAhULUAN}

Pemanfaatan teknologi berkembang pesat di masyarakat, dari yang hanya mampu mendengarkan suara melalui radio, kemudian dikembangkan dengan hadirnya televisi yang telah dapat menampilkan audio visual, kini telah ditransformasikan menjadi sebuah teknologi Portable seperti smartphone. Smartphone telah menjadi kebutuhan primer bagi masyarakat sekarang ini. Anak-anak, remaja dan bahkan orang tua tidak terlepas dari penggunaan teknologi smartphone.

Rumah kediaman Bung Karno merupakan salah satu bangunan bersejarah peninggalan Ir. 
Jurnal Pseudocode, Volume V Nomor 2, September 2018, ISSN 2355-5920, e-ISSN 2655-1845 www.ejournal.unib.ac.id/index.php/pseudocode

Soekarno semasa pengasingan yang terletak di kota Bengkulu. Letaknya yang berada di pusat kota Bengkulu menjadikannya salah satu obyek wisata utama kota Bengkulu. Kurangnya informasi dan media promosi yang kurang menarik dan tidak interaktif menyebabkan pengunjung yang datang ke lokasi ini masih sangat sedikit.

Pengenalan bangunan bersejarah di Kota Bengkulu (Monumen Thomas Parr, Benteng Marlborough, Monumen Inggris Robert Hamilton, Makam Inggris, Rumah Pengasingan Soekarno, Masjid Jamik Bengkulu, dan Rumah Fatmawati) yang telah dilakukan oleh Okrianto masih belum menampilkan bagian dalam dari bangunan bersejarah tersebut [1].

\section{LANDASAN TEORI}

\section{A. Augmented Reality}

Augmented Reality adalah teknologi yang menggabungkan benda maya dua dimensi ataupun tiga dimensi ke dalam sebuah lingkungan nyata, tiga dimensi lalu memproyeksikan benda-benda maya tersebut dalam waktu nyata. Tidak seperti realitas maya yang sepenuhnya menggantikan kenyataan, namun Augmented Reality hanya menambahkan atau melengkapi kenyataan [2].

Riset Augmented Reality bertujuan untuk mengembangkan teknologi yang memperbolehkan penggabungan secara real-time terhadap digital content yang dibuat oleh komputer dengan dunia nyata. Augmented Reality memperbolehkan pengguna melihat objek maya tiga dimensi yang diproyeksikan terhadap dunia nyata.(Emerging Technologies of Augmented Reality: Interfaces and Design). Augmented Reality pada dasarnya adalah sebuah konsep yang mencitrakan gambar tiga dimensi yang seolah nyata. Proses ini bisa diperinci menjadi beberapa proses dan komponen.
Untuk mencitrakan gambar tiga dimensi tersebut, sistem Augmented Reality terlebih dahulu harus melakukan penglihatan atau vision terhadap lingkungan yang padanya akan dicitrakan objek virtual. kemudian, dilakukanlah proses tracking terhadap objek spesifik yang menentukan letak citraan objek virtual tersebut. Kemudian, objek tersebut akan dikenali, atau dianalisis. Setelah dikenali dan dianalisis posisi dan orientasinya, maka komputer akan melakukan proses pencitraan objek tersebut, dan akan tampak pada perlengkapan display.

Komponen penting yang harus ada adalah:

a. Perlengkapan tampilan (display)

b. Alat tracking (pencarian)

c. Peralatan input

d. Perangkat komputer

Perlengkapan tampilan digunakan untuk menampilkan 'informasi' gambar atau objek tiga dimensi yang dicitrakan terhadap dunia nyata tempat user melihat. Perlengkapan tampilan terbagi menjadi tiga jenis, yakni Head Mounted Display, Handheld Display, dan Spatial Display. Head Mounted Display adalah perlengkapan tampilan yang dikenakan di kepala user dan digunakan sebagai 'kacamata' untuk melihat dunia nyata, yang telah digabungkan dengan objek virtual yang telah diregistrasikan dalam sistem, Handheld Display adalah perlengkapan ringkas yang dapat dibawa-bawa kemana saja dan dapat dimuat ditangan. Contohnya adalah smartphone dan android phone.

Spatial Display adalah sistem pencitraan yang menggunakan proyektor digital untuk mempetakan informasi grafis pada objek fisik. Yang paling membedakan Spatial Display adalah bahwa pencitraannya tidak terasosiasi dengan setiap individu user, namun secara berkelompok. 
Jurnal Pseudocode, Volume V Nomor 2, September 2018, ISSN 2355-5920, e-ISSN 2655-1845 www.ejournal.unib.ac.id/index.php/pseudocode

Tracking biasanya dilakukan dengan teknologiteknologi menangkap gambar, misalnya dengan kamera digital, sensor optis lainnya, GPS, kompas, dan lain sebagainya. Selain itu, alat tracking yang sekarang meningkat popularitasnya adalah webcam, karena praktis, kecil, mudah dibawa dan diatur untuk dijalankan. Peralatan input hingga sekarang ini masih banyak menjadi objek penelitian.

Hingga saat ini, alat yang digunakan mencakup alat 'pinch glove', tongkat bertombol, atau peralatan handheld seperti smartphone. Perangkat komputer, terutama dengan CPUyang kuat dan jumlah RAM yang cukup besar untuk memproses gambar yang ditangkap. Sistem yang digunakan untuk mobilitas biasanya menggunakan laptop yang dilengkapi dengan webcam, sementara untuk yang bersifat diam menggunakan workstation dengan kartu grafis yang kuat [3].

\section{B. Markerless Augmented Reality}

Salah satu metode Augmented Reality yang saat ini sedang berkembang adalah metode Markerless Augmented Reality, dengan metodeini pengguna tidak perlu lagi menggunakan sebuah marker untuk menampilkan elemen-elemen digital. [4]. Seperti yang saat ini dikembangkan oleh perusahaan Augmented Reality terbesar di dunia Total Immersion dan Qualcomm, mereka telah membuat berbagai macam teknik Markerless Tracking sebagai teknologi andalan mereka, seperti Face Tracking, 3D Object Tracking, dan Motion Tracking.

a. Face Tracking

Algoritme yang mereka kembangkan, komputer dapat mengenali wajah manusia secara umum dengan cara mengenali posisi mata, hidung, dan mulut manusia, kemudian akan mengabaikan objek-objek lain di sekitarnya seperti pohon, rumah, danbenda-benda lainnya.

b. 3D Object Tracking

Berbeda dengan Face Tracking yang hanya mengenali wajah manusia secara umum, teknik 3D Object Tracking dapat mengenali semua bentuk benda yang ada disekitar, seperti mobil, meja, televisi, dan lain-lain.

c. Motion Tracking

Pada teknik ini komputer dapat menangkap gerakan, MotionTrackingtelah mulai digunakan secara ekstensif untuk memproduksi film-film yang mencoba mensimulasikan gerakan.

\section{Sweet Home 3D}

Sweet Home 3D adalah sebuah program gratis (freeware) yang digunakan untuk membuat tampilan visualisasi interior 3 dimensi secara mudah dan cepat. Saking mudahnya, telah menempatkan Sweet Home 3D menjadi program animasi yang mudah dan populer dibandingkan program aplikasi sejenis [5].

\section{Vuforia SDK}

Vuforia adalah Augmented Reality Software Development Kit (SDK) untuk perangkat mobile yang memungkinkan pembuatan aplikasi Augmented Reality. Dulunya lebih dikenal dengan QCAR (Qualcomm Company Augmentend Reality). Ini menggunakan teknologi Computer Vision untuk mengenali dan melacak gambar planar (Target Image) dan objek 3D sederhana, seperti kotak, secara real-time. Kemampuan registrasi citra memungkinkan pengembang untuk mengatur posisi dan virtual orientasi objek, seperti model 3D dan media lainnya, dalam kaitannya dengan gambar dunia nyata ketika hal ini dilihat melalui kamera perangkat mobile. Obyek maya 
Jurnal Pseudocode, Volume V Nomor 2, September 2018, ISSN 2355-5920, e-ISSN 2655-1845 www.ejournal.unib.ac.id/index.php/pseudocode

kemudian melacak posisi dan orientasi dari gambar secara real-time sehingga perspektif pengguna pada objek sesuai dengan perspektif mereka pada Target Image, sehingga muncul bahwa objek virtual adalah bagian dari adegan dunia nyata.[6].

SDK Vuforia mendukung berbagai jenis target 2D dan 3D termasuk Target Gambar 'markerless', 3D Multi target konfigurasi, dan bentuk MarkerFrame. Fitur tambahan dari SDK termasuk Deteksi Oklusi local menggunakan 'Tombol virtual', runtime pemilihan gambar target, dan kemampuan untuk membuat dan mengkonfigurasi ulang set pemrograman pada saat runtime. Vuforia menyediakan Application Programming Interfaces (API) di C++, Java, Objective-C. SDK mendukung pembangunan untuk IOS dan Android menggunakan Vuforia karena itu kompatibel dengan berbagai perangkat mobile termasuk iPhone (4/4S), iPad, dan ponsel Android dan tablet yang menjalankan Android OS versi 2.2 atau yang lebih besar dan prosesor ARMv6 atau 7 dengan FPU (Floating Point Unit) kemampuan pengolahan [6].

Qualcomm Augmented Reality memberikan beberapa keuntungan seperti:

a. Teknologi computer vision untuk menyelaraskan gambar yang tercetak dan object 3D.

b. Mendukung beberapa alat development seperti Eclipse, Android, Xcode.

Selain itu, QCAR juga menawarkan development dan distribusi yang gratis.

\section{E. Android}

Android adalah sistem operasi untuk telepon mobile yang berbasis Linux yang mencakup sistem opersi, middleware dan aplikasi.Android menyediakan platform terbuka bagi para pengembang untuk menciptakan aplikasi mereka sendiri untuk digunakan oleh bermacam peranti bergerak. Awalnya, Google Inc. membeli Android Inc., pendatang baru yang membuat peranti lunak untuk ponsel. Kemudian untuk mengembangkan Android, dibentuklah Open Handset Alliance, konsorsium dari 34 perusahaan peranti keras, peranti lunak, dan telekomunikasi, termasuk Google, HTC, Intel, Motorola, Qualcomme, TMobile, dan Nvidia [7].

\section{F. Android SDK}

Android SDK (Software Development Kit) adalah tools API (Application Programming Interface) yang diperlukan untuk memulai pengembangan suatu aplikasi pada platform android menggunakan bahasa pemrograman Java. Android merupakan subset perangkat lunak untuk ponsel yang meliputi sistem operasi, middleware dan aplikasi kunci yang direlease oleh Google. Saat ini disediakan Android SDK sebagai alat bantu dan API untuk mulai mengembangkan aplikasi pada platform android menggunakan bahasa pemrograman Java. Sebagai platform aplikasi netral, android memberi anda kesempatan untuk membuat aplikasi yang kita butuhkan yang bukan aplikasi bawaan Handphone/smartphone [8].

Beberapa fitur android yang paling penting adalah:

1. Framework Aplikasi yang mendukung penggantian komponen dan reusable.

2. Mesin Virtual Dalvik dioptimalkan untuk perangkat mobile.

3. Integrated browser berdasarkan engine open source WebKit. 
Jurnal Pseudocode, Volume V Nomor 2, September 2018, ISSN 2355-5920, e-ISSN 2655-1845 www.ejournal.unib.ac.id/index.php/pseudocode

4. Grafis yang dioptimalkan dan didukung oleh libraries grafis 2D, grafis 3D berdasarkan spesifikasi openGL ES1.0 (Opsional akselerasi hardware).

5. SQLite untuk menyimpan data.

6. Media support yang mendukunga audio, video dan gambar.

\section{METODE RISET}

\section{G. Model Pengembangan Sistem}

Model pengembangan sistem dalam penelitian ini menggunakan incremental model [9].

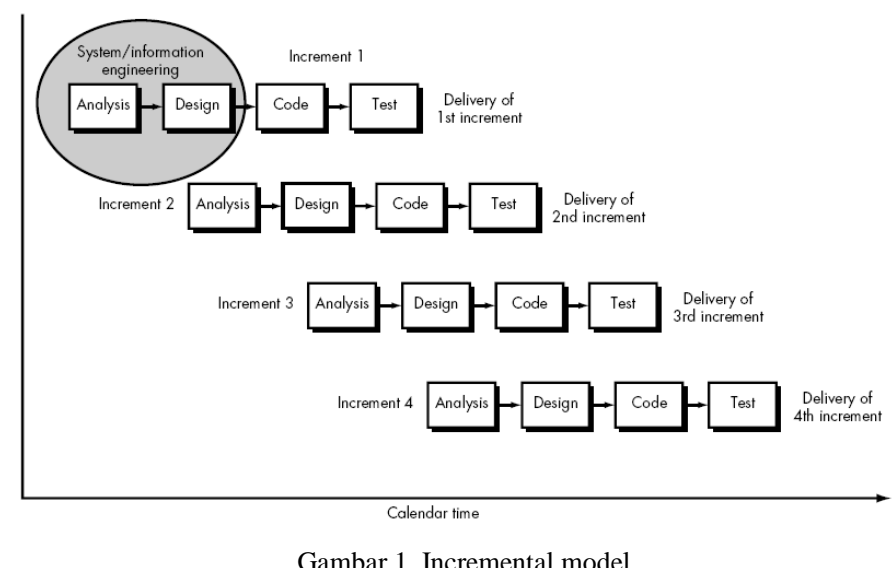

Gambar 1. Incremental model

\section{H. Flowchart Sistem}

Flow chart dalam penelitian ini mengikuti gambar di bawah ini

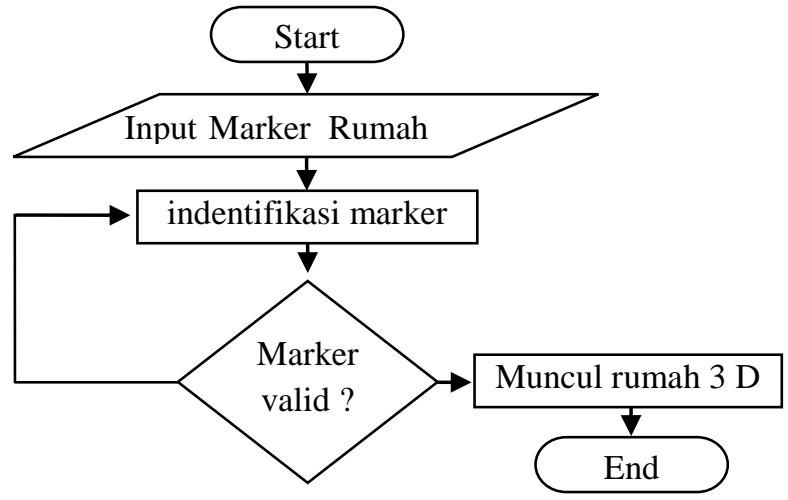

Gambar 2. Flowchart Sistem

\section{Diagram Use Case}

Use case dalam penelitian ini adalah sebagai berikut: 
Jurnal Pseudocode, Volume V Nomor 2, September 2018, ISSN 2355-5920, e-ISSN 2655-1845 www.ejournal.unib.ac.id/index.php/pseudocode

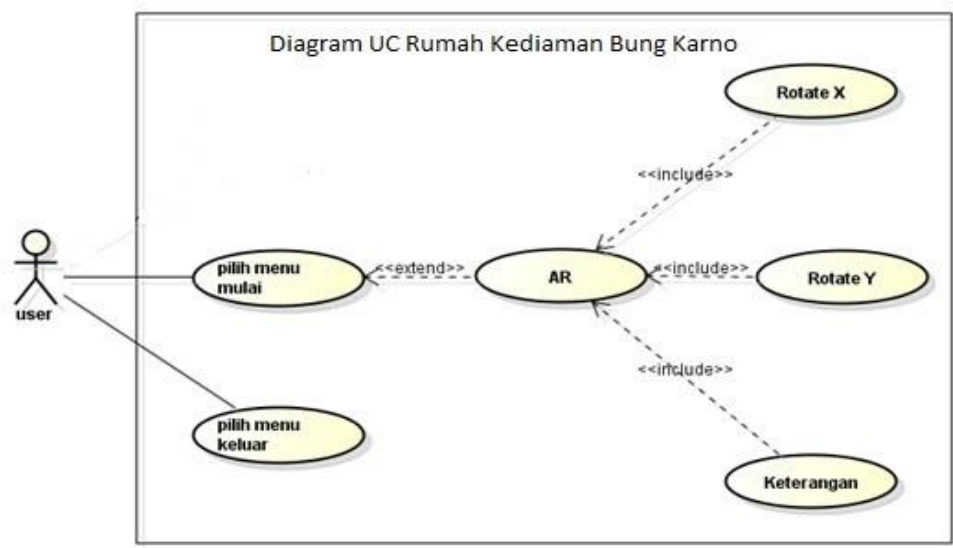

Gambar 3. Use Case Diagram

IV. HASIL DAN PEMBAHASAN

\section{J. Pembuatan Marker}

Pada penelitian ini penulis membuat sebuah brosur yang berisi kan sebuah marker. Brosur tersebut merupakan sebuah kertas yang berukuran 210 x $297 \mathrm{~mm}$ dan berfungsi sebagai objek dari proses berjalannya aplikasi.

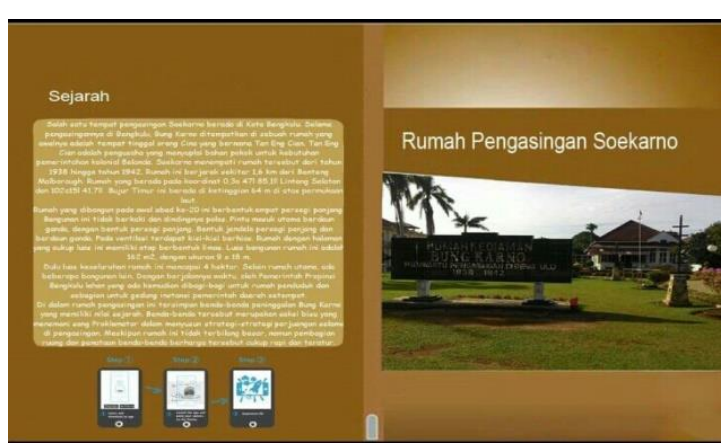

Gambar 4. Marker AR Rumah Bung Karno

\section{K. Hasil Aplikasi}

Pada saat aplikasi dijalankan maka yang pertama kali muncul adalah splash screen seperti yang pada gambar di bawah ini.

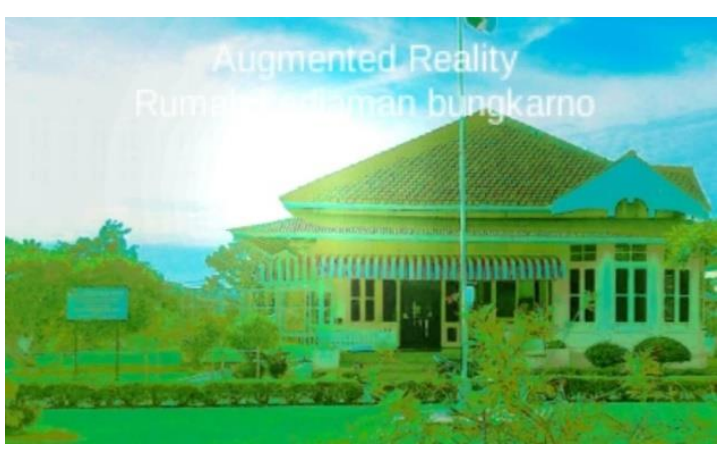

Gambar 5. Splash Screen
Tampilan menu aplikasi yang telah dibuat terdiri dari 2 tombol yaitu GO AR dan Exit seperti gambar di bawah ini

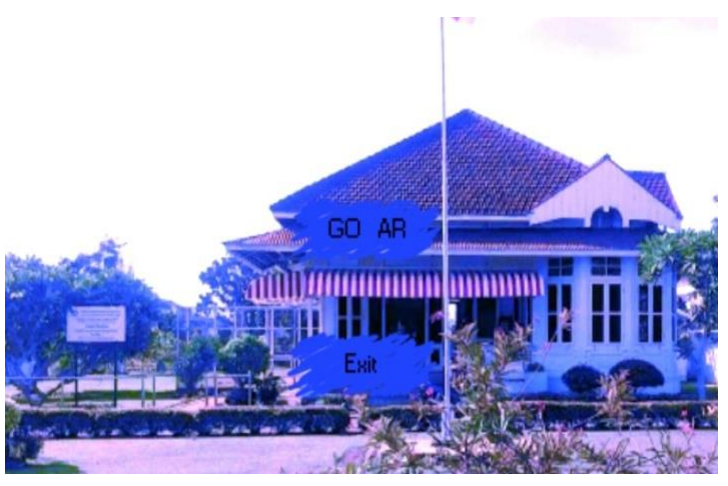

Gambar 6. Menu Aplikasi

Pada aplikasi ini kita sudah dapat melihat Rumah Pengasingan Bung karno dari luar maupun bagian dalam rumah seperti terlihat pada gambar di bawah ini.

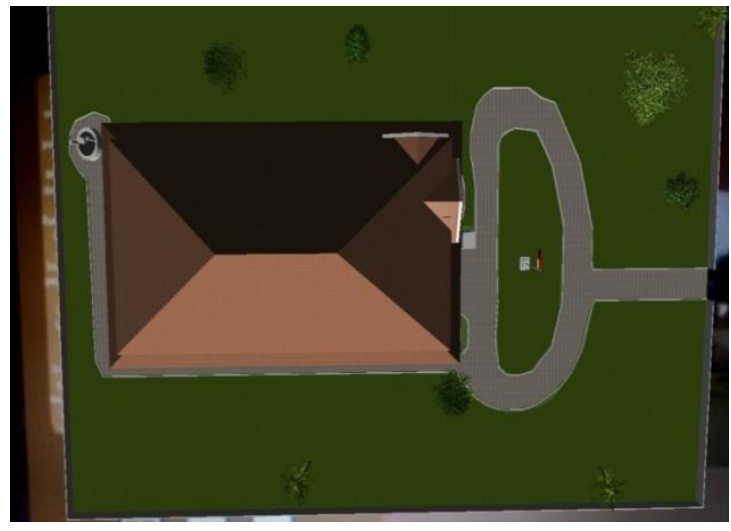

Gambar 7. AR Rumah Bung Karno Tampak Luar 
Jurnal Pseudocode, Volume V Nomor 2, September 2018, ISSN 2355-5920, e-ISSN 2655-1845 www.ejournal.unib.ac.id/index.php/pseudocode

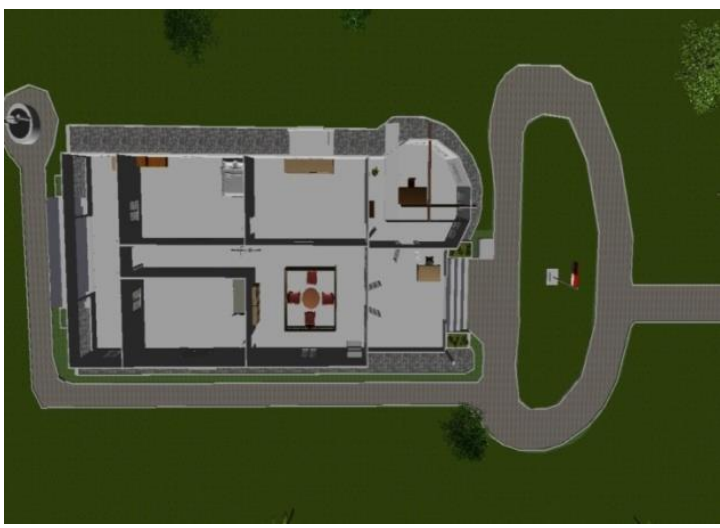

Gambar 8. AR Rumah Bung Karno Tampak Dalam

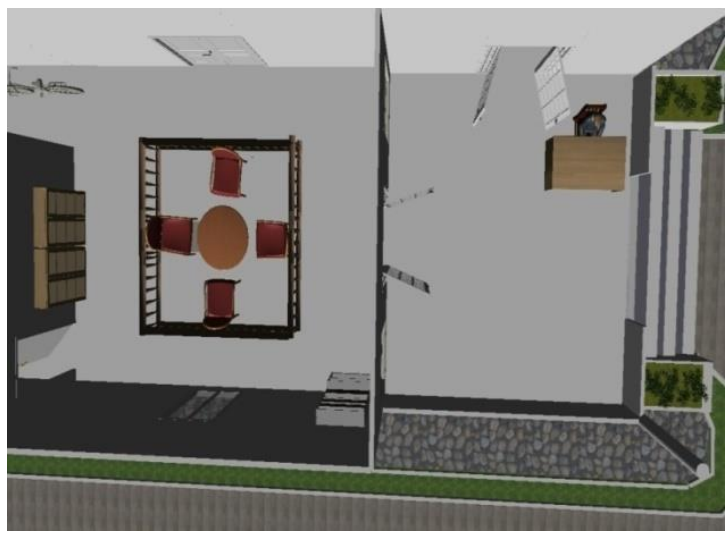

Gambar 9. AR Rumah Bung Karno Tampak Dalam Bagian Depan

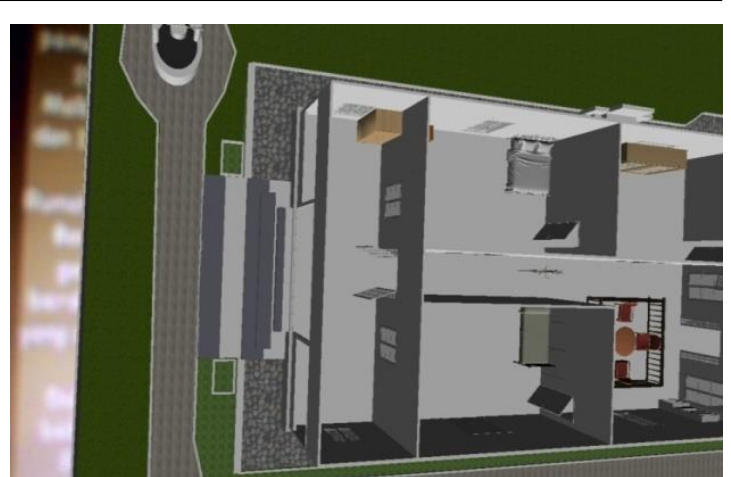

Gambar 10. AR Rumah Bung Karno Tampak Dalam Bagian Belakang

\section{Pengujian Aplikasi}

Pengujian Aplikasi dalam penelitian ini menggunakan marker selembar katalog yang telah dibuat sebelumnya sesuai pada Gambar 4.

Hasil pengujian jarak kamera dan marker, pantulan cahaya dan sudut kemiringan kamera dapat dilihat pada table berikut.

Tabel 1. Pengujian Marker

\begin{tabular}{|c|c|c|c|c|}
\hline No. & Jarak (cm) & $\begin{array}{c}\text { Sudut kemiringan } \\
\text { kamera }\end{array}$ & $\begin{array}{c}\text { Pencahayaan (cahaya lampu, sinar } \\
\text { matahari, berawan, gelap) }\end{array}$ & $\begin{array}{c}\text { Tingkat } \\
\text { keberhasilan }\end{array}$ \\
\hline 1. & 4 & $0^{0}$ & $\begin{array}{l}\text { Cahaya lampu, gelap } \\
\left(10 \mathrm{~lm} / \mathrm{m}^{2}\right)\end{array}$ & Tidak berhasil \\
\hline 2. & 4 & $0^{0}$ & $\begin{array}{l}\text { Sinar matahari, berawan } \\
\left(160 \mathrm{~lm} / \mathrm{m}^{2}\right)\end{array}$ & Tidak berhasil \\
\hline 3. & 8 & $0^{0}$ & $\begin{array}{l}\text { Cahaya lampu, gelap } \\
\left(10 \mathrm{~lm} / \mathrm{m}^{2}\right)\end{array}$ & Tidak berhasil \\
\hline 4. & 8 & $0^{0}$ & $\begin{array}{l}\text { Sinar matahari, berawan } \\
\left(160 \mathrm{~lm} / \mathrm{m}^{2}\right)\end{array}$ & Berhasil \\
\hline 5. & 12 & $0^{0}$ & $\begin{array}{l}\text { Cahaya lampu, gelap } \\
\left(10 \mathrm{~lm} / \mathrm{m}^{2}\right)\end{array}$ & Tidak berhasil \\
\hline 6. & 12 & $0^{0}$ & $\begin{array}{l}\text { Sinar matahari, berawan } \\
\left(160 \mathrm{~lm} / \mathrm{m}^{2}\right)\end{array}$ & Berhasil \\
\hline 7. & 27 & $0^{0}$ & $\begin{array}{l}\text { Cahaya lampu, gelap } \\
\left(10 \mathrm{~lm} / \mathrm{m}^{2}\right)\end{array}$ & Tidak berhasil \\
\hline 8. & 27 & $0^{0}$ & $\begin{array}{l}\text { Sinar matahari, berawan } \\
\left(160 \mathrm{~lm} / \mathrm{m}^{2}\right)\end{array}$ & Berhasil \\
\hline 9. & 50 & $0^{0}$ & $\begin{array}{l}\text { Cahaya lampu, gelap } \\
\left(10 \mathrm{~lm} / \mathrm{m}^{2}\right)\end{array}$ & Tidak berhasil \\
\hline 10. & 50 & $0^{0}$ & $\begin{array}{l}\text { Sinar matahari, berawan } \\
\left(160 \mathrm{~lm} / \mathrm{m}^{2}\right)\end{array}$ & Berhasil \\
\hline 11. & 4 & $45^{0}$ & $\begin{array}{l}\text { Cahaya lampu, gelap } \\
\left(10 \mathrm{~lm} / \mathrm{m}^{2}\right)\end{array}$ & Tidak berhasil \\
\hline 12. & 4 & $45^{\circ}$ & $\begin{array}{l}\text { Sinar matahari, berawan } \\
\left(160 \mathrm{~lm} / \mathrm{m}^{2}\right)\end{array}$ & Tidak berhasil \\
\hline 13. & 8 & $45^{0}$ & $\begin{array}{l}\text { Cahaya lampu, gelap } \\
\left(10 \mathrm{~lm} / \mathrm{m}^{2}\right)\end{array}$ & Tidak berhasil \\
\hline
\end{tabular}


Jurnal Pseudocode, Volume V Nomor 2, September 2018, ISSN 2355-5920, e-ISSN 2655-1845 www.ejournal.unib.ac.id/index.php/pseudocode

\begin{tabular}{|c|c|c|c|c|}
\hline No. & Jarak (cm) & $\begin{array}{c}\text { Sudut kemiringan } \\
\text { kamera }\end{array}$ & $\begin{array}{c}\text { Pencahayaan (cahaya lampu, sinar } \\
\text { matahari, berawan, gelap) }\end{array}$ & $\begin{array}{c}\text { Tingkat } \\
\text { keberhasilan }\end{array}$ \\
\hline 14. & 8 & $45^{0}$ & $\begin{array}{l}\text { Sinar matahari, berawan } \\
\left(160 \mathrm{~lm} / \mathrm{m}^{2}\right)\end{array}$ & Berhasil \\
\hline 15. & 12 & $45^{0}$ & $\begin{array}{l}\text { Cahaya lampu, gelap } \\
\left(10 \mathrm{~lm} / \mathrm{m}^{2}\right)\end{array}$ & Tidak berhasil \\
\hline 16. & 12 & $45^{0}$ & $\begin{array}{l}\text { Sinar matahari, berawan } \\
\left(160 \mathrm{~lm} / \mathrm{m}^{2}\right)\end{array}$ & Berhasil \\
\hline 17. & 27 & $45^{0}$ & $\begin{array}{l}\text { Cahaya lampu, gelap } \\
\left(10 \mathrm{~lm} / \mathrm{m}^{2}\right)\end{array}$ & Tidak berhasil \\
\hline 18. & 27 & $45^{0}$ & $\begin{array}{l}\text { Sinar matahari, berawan } \\
\left(160 \mathrm{~lm} / \mathrm{m}^{2}\right)\end{array}$ & Berhasil \\
\hline 19. & 50 & $45^{0}$ & $\begin{array}{l}\text { Cahaya lampu, gelap } \\
\left(10 \mathrm{~lm} / \mathrm{m}^{2}\right)\end{array}$ & Tidak berhasil \\
\hline 20. & 50 & $45^{0}$ & $\begin{array}{l}\text { Sinar matahari, berawan } \\
\left(160 \mathrm{~lm} / \mathrm{m}^{2}\right)\end{array}$ & Berhasil \\
\hline 21. & 4 & $70^{\circ}$ & $\begin{array}{l}\text { Cahaya lampu, gelap } \\
\left(10 \mathrm{~lm} / \mathrm{m}^{2}\right)\end{array}$ & Tidak berhasil \\
\hline 22. & 4 & $70^{\circ}$ & $\begin{array}{l}\text { Sinar matahari, berawan } \\
\left(1601 \mathrm{~m} / \mathrm{m}^{2}\right)\end{array}$ & Tidak berhasil \\
\hline 23. & 8 & $70^{\circ}$ & $\begin{array}{l}\text { Cahaya lampu, gelap } \\
\left(10 \mathrm{~lm} / \mathrm{m}^{2}\right)\end{array}$ & Tidak berhasil \\
\hline 24. & 8 & $70^{\circ}$ & $\begin{array}{l}\text { Sinar matahari, berawan } \\
\left(160 \mathrm{~lm} / \mathrm{m}^{2}\right)\end{array}$ & Berhasil \\
\hline 25. & 12 & $70^{\circ}$ & $\begin{array}{l}\text { Cahaya lampu, gelap } \\
\left(10 \mathrm{~lm} / \mathrm{m}^{2}\right)\end{array}$ & Tidak berhasil \\
\hline 26. & 12 & $70^{\circ}$ & $\begin{array}{l}\text { Sinar matahari, berawan } \\
\left(160 \mathrm{~lm} / \mathrm{m}^{2}\right)\end{array}$ & Berhasil \\
\hline 27. & 27 & $70^{\circ}$ & $\begin{array}{l}\text { Cahaya lampu, gelap } \\
\left(10 \mathrm{~lm} / \mathrm{m}^{2}\right)\end{array}$ & Tidak berhasil \\
\hline 28. & 27 & $70^{\circ}$ & $\begin{array}{l}\text { Sinar matahari, berawan } \\
\left(160 \mathrm{~lm} / \mathrm{m}^{2}\right)\end{array}$ & Berhasil \\
\hline 29. & 50 & $70^{\circ}$ & $\begin{array}{l}\text { Cahaya lampu, gelap } \\
\left(10 \mathrm{~lm} / \mathrm{m}^{2}\right)\end{array}$ & Tidak berhasil \\
\hline 30. & 50 & $70^{\circ}$ & $\begin{array}{l}\text { Sinar matahari, berawan } \\
\left(160 \mathrm{~lm} / \mathrm{m}^{2}\right)\end{array}$ & Berhasil \\
\hline
\end{tabular}

Pengujian dilakukan dengan jarak $4 \mathrm{~cm}, 8 \mathrm{~cm}$, $12 \mathrm{~cm}, 27 \mathrm{~cm}, 50 \mathrm{~cm}$ dan dipengaruhi cahaya minimal pada $100 \mathrm{~lm} / \mathrm{m} 2$ maksimum $400 \mathrm{~lm} / \mathrm{m} 2$ dan kemiringan kamera. Jarak minimum marker terhadap kamera yaitu $12 \mathrm{~cm}$ dengan sudut minimum $0^{0}$ dan sudut maksimum $70^{\circ}$. Jarak minimum dan maksimum serta sudut kemiringan kamera minimum - maksimum diperngaruhi oleh cahaya, dimana dalam pengujian apabila ada pantulan cahaya maka augmented reality (3D rumah) tidak akan muncul.

\section{KesIMPULAN}

Kesimpulan pada penelitian ini adalah:

1. Dengan adanya system aplikasi augmented reality dapat mempermudah pengguna untuk melihat Rumah Kediaman Bung Karno tanpa harus berkunjung ke lokasi.

2. Jarak dalam proses tracking yang baik: $27 \mathrm{~cm}$, sedang: $8-27 \mathrm{~cm}$, buruk: kurang dari $4 \mathrm{~cm}$ dan lebih dari $50 \mathrm{~cm}$

3. Sudut pandang dalam proses tracking yang baik: $0-45^{\circ}$, sedang: $75^{\circ}$, buruk: lebih dari $75^{\circ}$.

4. Cahaya sangat dibutuhkan dalam proses tracking ini, cahaya yang baik: 100 lm/m2 maksimum $400 \mathrm{~lm} / \mathrm{m} 2$ tidak terlalu terang, buruk : tidak ada cahaya atau cahaya terlalu terang. 
Jurnal Pseudocode, Volume V Nomor 2, September 2018, ISSN 2355-5920, e-ISSN 2655-1845 www.ejournal.unib.ac.id/index.php/pseudocode

\section{SARAN}

Saran untuk pengembangan penelitian kedepan adalah:

1. Perlu dilakukan penelitian lanjutan dengan penambahan audio atau bahkan video, membuat objek jauh lebih iteraktif

2. Mengganti marker menjadi lebih menarik mungkin tanpa marker atau markerless.

3. Penambahan pergerakkan objek menggunakan touch.

\section{REFERENSI}

[1] Okrianto, MS.Erlansari, Aan. Ernwati" Aplikasi AR-HB (augmented reality and historical building) sebagai media promosi dan pengenalan Bangunan bersejarah Di kota Bengkulu”,Jurnal Rekursif, Bengkulu, 2018.

[2] Azuma, Ronald T. (august 1997). Journal : "A survey of Augmented Reality". Presence: Teleoperators and virtual Environment

[3] Haller, Billinghurst, dan Thomas. (2007). "Emerging Technologies of Augmented Reality": Interfaces and Design

[4] Andrew I. Comport. (2006). "Real-Time Markerless Tracking for Augmented Reality" : The Virtual Visual Serving Framework

[5] http://www.sweethome3d.com

[6] www.qualcomm.com

[7] Nazruddin, S. H. (2011). Android : Pemrograman Aplikasi Mobile Smartphone dan Tablet.

[8] Swalt, mengenal JDK, SDK, AVD dan ECLIPSE, http://www.swalt.info/pemograman/android/115-

mengenal-jdk-sdk-avd- dan-eclipse.html, Agarwal, Bharat Bhusnan.,Tayal, Sumit Prakash" Software Engineering $2^{\text {nd }}$ Ed. Firewall Media,. New Delhi, 2009 